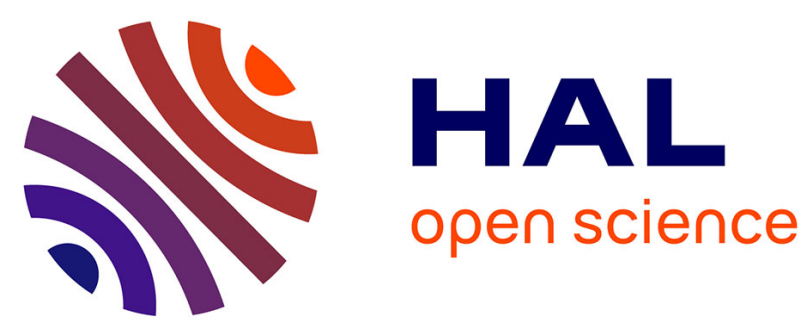

\title{
Investigation of mechanisms governing membrane fouling and protein rejection in the sterile microfiltration of beer with an organic membrane
}

Pascal Blanpain-Avet, Luc Fillaudeau, M. Lalande

\section{- To cite this version:}

Pascal Blanpain-Avet, Luc Fillaudeau, M. Lalande. Investigation of mechanisms governing membrane fouling and protein rejection in the sterile microfiltration of beer with an organic membrane. Food and Bioproducts Processing, 1999, 77 (7), pp.75-89. hal-02697286

\section{HAL Id: hal-02697286 \\ https: / hal.inrae.fr/hal-02697286}

Submitted on 1 Jun 2020

HAL is a multi-disciplinary open access archive for the deposit and dissemination of scientific research documents, whether they are published or not. The documents may come from teaching and research institutions in France or abroad, or from public or private research centers.
L'archive ouverte pluridisciplinaire HAL, est destinée au dépôt et à la diffusion de documents scientifiques de niveau recherche, publiés ou non, émanant des établissements d'enseignement et de recherche français ou étrangers, des laboratoires publics ou privés. 


\title{
INVESTIGATION OF MECHANISMS GOVERNING MEMBRANE FOULING AND PROTEIN REJECTION IN THE STERILE MICROFILTRATION OF BEER WITH AN ORGANIC MEMBRANE
}

\author{
P. BLANPAIN-AVET, L. FILLAUDEAU and M. LALANDE \\ INRA-LGPTA, Villeneuve d'Ascq, France
}

\begin{abstract}
ince the early 1980s, cold sterile crossflow microfiltration has been evaluated as a potential alternative to conventional thermal processes in the brewing industry (flash-or tunnel pasteurization). Up to now, industrial membrane development for beer microfiltration was limited both by severe membrane fouling and by protein and aroma compound retention.

In the present work, fouling mechanisms and protein rejection have been investigated experimentally at laboratory scale for the microfiltration of a clarified (kieselguhr filtered) beer through a $0.2 \mu \mathrm{m}$ polycarbonate membrane. Fouling mechanisms were analysed by using the constant pressure blocking filtration laws for which interactions arise between high molecular weight beer components and the membrane matrix resulting in pore constrictions and progressive blockage. Protein content in beer was measured using two dye-binding methods (Bradford and Lowry).

It was found that permeate flux decay was governed by two successive fouling mechanisms: an internal pore fouling at the initial stages of filtration that conforms to the standard blocking model, followed by an external surface fouling conforming to the cake filtration model. The variation with time of membrane selectivity was characterized by a high initial protein transmission rate followed by a sharp decrease that occurs in a range of filtered volumes which is independent of the applied transmembrane pressure. For all experiments, protein retention level throughout the filtration was found to be closely related to the nature of fouling. It remains constant and low $(<20 \%)$ in the presence of a pore diameter decrease induced by lateral adsorption of macrosolutes, then increases abruptly (up to 60\%) and stabilizes when a fouling layer (gel layer) forms over the membrane surface. The significant role played in the composition of this limiting surface fouling layer by proteins (associated with polyphenols and $\beta$-glucans to form proteinaceous haze material) has been highlighted. The understanding of membrane fouling phenomena (such as the nature and location of fouling materials) is liable to lead to the design of efficient cleaning procedures for the sterile microfiltration of beer.
\end{abstract}

Keywords: microfiltration; beer; protein retention; membrane fouling; pore blocking law

\section{INTRODUCTION}

In the brewing industry, beer filtration is one of the most important operations in the brewing process. At the final step of beer processing, beer clarification (i.e. the separation of the remaining yeast as well as the haze-forming materials formed during beer lagering) is currently obtained by using filter-aids (kieselguhr) during dead-end filtration. A flash pasteurization process involving a plate heat exchanger is then necessary to ensure the microbial stability of the final product. A microbiological stability between 3 and 6 months can be ensured when the level of one yeast cell per millilitre is reached, which represents a admissible standard with the common filtration techniques (usually using the combination of kieselguhr filter, sheet filter and membrane filter).
For a number of years, crossflow microfiltration (CFMF) has been investigated as an alternative process for the colloidal and microbiological stabilization of beer. Membrane CFMF has been evaluated by brewers for some years as an alternative to pasteurization in order to produce cold stabilized beer safely and economically ${ }^{1,2}$. From a theoretical point of view, the microfiltration process can replace both beer clarification and sterilization by combining these two operations into a single crossflow process. It is the combination of the two operations in a single stage which enables CFMF to be justified on economic grounds alone.

Two types of process are available for the brewer to achieve beer sterilization: i) thermal process, i.e. flash- (or tunnel) pasteurization and ii) cold filtration with either membrane filter cartridges or crossflow microfiltration membranes. Crossflow microfiltration for use in the area 
of cold sterile beer filtration must comply with the following specifications ${ }^{3}$ :

- retention of beer-spoilage organisms (bacteria and yeasts) in the cold temperature area;

- no negative changes of essential beer constituents;

- effective cleaning and sanitization of the membranes with cleaning agents (alkaline, acid, oxidative cleaning) and disinfectants (e.g. with chlorinated sanitizers),

- membrane with a narrow pore size distribution,

- easy operation,

- sufficiently long life/adequate economics.

Flash pasteurization and membrane CFMF have various advantages and disadvantages when compared directly for beer sterilization, which often appear to be minimal but which nevertheless in the long term may have significant consequences. In the following, the processes of flash pasteurization and membrane CFMF are compared in terms of biological safety and economics, and their advantages and disadvantages are listed.

\section{Membrane CFMF}

The main advantages and disadvantages of membrane CFMF which can be highlighted are:

\section{Advantages}

- membranes can be inspected for integrity before filtration (e.g. bubble point measurement), which guarantees impeccably sterile filtrates;

- the crossflow filtration system can be installed as fully automatic units and all processes can be controlled and monitored improving thus productivity;

- possible negative effects on beer quality due to heat treatment are avoided, no microorganisms which have been killed off remain in the beer;

- the natural fresh flavour of the beer is retained (natural 'freshness' argument);

- good pressure stability (absence of momentary slip-leak of microorganisms from pressure surges);

- rapid developments are occurring in new membrane technologies for organic and inorganic types to achieve increased tenacity, chemical and temperature resistance, higher permeate fluxes and also a more regular pore size distribution.

\section{Disadvantages}

- membrane fouling resulting in a reduction of the permeate flux to far below the theoretical capacity of the membrane (steady-state fluxes are typically below $1001 . \mathrm{h}^{-1} \cdot \mathrm{m}^{-2}$ );

- chemical and organoleptic analysis of beer before and after membrane CFMF has confirmed that there is detectable change in the beer quality after filtration (e.g. retention of flavour-active constituents and decrease of the foam stability);

- residual risks associated with the presence of small-cell beer contaminants such as L lindneri, $L$ casei, L coryniformis and L brevisimilis;

- for a given membrane, permeate flux may vary significantly with respect to different beers (e.g. Lager beer compared to dark types, Altbier) of various filterability; - the costs which are in any case twice or three times higher than in flash pasteurization (according to producers).

\section{Flash Pasteurization}

The main advantages and disadvantages (or risks) associated with flash pasteurization which can be put forward are ${ }^{4}$ :

\section{Advantages}

- it is certain that kill-off is ensured independent of the type of microbe, the morphology, the physiological condition or the contamination count;

- pressure fluctuations or irregularities in beer flow arising from switchover procedures or disturbances in bottling do not affect kill-off;

- the costs are lowest comparative to all other processes (according to producers).

\section{Disadvantages}

- technologists usually regard taste stability as a very major disadvantage; this is applied especially to sensitive, pale beers (e.g. Pilsener);

- heat treatment results in a high energy consumption;

- heating of beers up to normal pasteurization temperature may be responsible for a part denaturation (e.g. Maillard reaction) of some beer components; it may destroy or volatilize important flavour-producing components that are required for a draft-beer taste and odour.

To sum up, it appears that as far as no technical deficiencies arise and the pasteurization units are adequately achieved, flash pasteurization is the safest and cheapest beer sterilization process. Although membrane CFMF is a means of acquiring a microbiologically-free, finished draft beer before packaging, the membrane crossflow process is currently still uneconomic against flash pasteurization. This situation is primarily due to strong membrane fouling resulting in unacceptable low permeate flux and essential quality components retention. The limitation of fouling, and the resulting regeneration and effective cleaning of the membranes, are the key factors for the economical feasibility of membrane processes for cold sterile microfiltration of beer.

Fouling in beer CFMF implies several different mechanisms, such as:

- gel layer formation ${ }^{5,6}$ and concentration polarization ${ }^{7}$;

- cake layer formation ${ }^{8-12}$;

- pore blocking and in-depth adsorption/deposition ${ }^{9-14}$.

The significant role played in membrane fouling by the molecular fractions (proteins ${ }^{6,15,16}, \quad \beta$-glucans ${ }^{17}$, pentosans ${ }^{16}$ etc.) which make up the colloidal haze of beer (protein-polyphenol associations together with high molecular weight polysaccharides) has been suggested. There is currently little understanding of the local phenomenology of membrane-solute interactions involved during beer CFMF because of the complex nature of beer which contains a large variety of molecular and colloidal fractions.

This study investigates fouling mechanisms and protein retention throughout the filtration in the sterilizing microfiltration of a (kieselguhr filtered) clarified beer. Most measurements were made with a capillary pore polycarbonate (PC) membrane and some comparative measurements with a capillary pore aluminium oxide $\left(\mathrm{Al}_{2} \mathrm{O}_{3}\right)$ membrane. 


\section{THEORY: CONSTANT PRESSURE BLOCKING FILTRATION LAWS}

A first approach to understand the mechanisms and the nature (internal, external) of fouling consists of using the socalled classical filtration laws (or pore blocking filtration laws, derived by Hermia ${ }^{18}$ ) for the interpretation of permeate flux decline with time. The use of the classical filtration models has the advantage of a non-ambiguous interpretation of often complex phenomena that limit the filtration rate of a solution coming from a fermentation broth which contains macrosolutes and suspended colloids with large size distribution. Pore blocking laws enables one to describe the interactions between high molecular weight beer components and porous structure of the membrane. Solute-membrane interactions result in either an effective decrease of pore diameter or a pore blockage at the membrane surface. Filtration laws form part of resistance models which are based upon Darcy's law for which at any instant during the filtration process, the flow rate $Q$ is given by:

$$
Q=P S /\left(\mu . R_{t}\right)
$$

where $P$ is the transmembrane pressure $(\mathrm{Pa}), S$ the membrane surface area $\left(\mathrm{m}^{2}\right), \mu$ the dynamic filtrate viscosity (Pas) and $R_{t}$ the total membrane resistance $\left(\mathrm{m}^{-1}\right)$.

A summary description of the assumptions included and the fouling mechanisms for each blocking filtration law is given in the Appendix.

\section{MATERIALS AND METHODS Filtration Module}

Filtration experiments have been conducted on a deadend filtration cell with a capacity of $200 \mathrm{ml}$. The cell diameter was $4.7 \mathrm{~cm}$ and the effective membrane area was $12.5 \mathrm{~cm}^{2}$. Stirring was provided by a magnetic stirring bar suspended $1.5 \mathrm{~mm}$ from the membrane surface. Stirring speed could be varied from 0 to $1000 \mathrm{rpm}$. The operating pressure was supplied by a compressed carbon dioxide line and was varied from 10 to $100 \mathrm{kPa}$. The transmembrane pressure of filtration was measured with a relative pressure sensor using a diffused strain gauge into a silicon crystal (JPB TA X 203) placed on the feed reservoir. Temperature of the feed solution was measured using a platinum resistance probe (Comptoir Lyon Allemand, $100 \Omega 0^{\circ} \mathrm{C}$ ) placed into the feed reservoir. Beer temperature was fixed at $0^{\circ} \mathrm{C}$ by a double casing around the filtration cell and feed reservoir. An electronic balance was used for measuring the filtrate flow rate and the filtrate volume. The signals from the balance and sensors were treated using an IBM/PC microcomputer through an analog/digital interface. Experiments were performed at atmospheric pressure with a beer from which $\mathrm{CO}_{2}$ had been removed.

The beer was a Lager beer coming from the downstream side of a kieselguhr sheet filter (Terken Brewery, Roubaix, France) with less than 5 yeast cells per $100 \mathrm{ml}$ and a haze below $1 \mathrm{EBC}^{19}$ (European Brewery Convention turbidity unit). As the beer was supplied from the same brewery, it could be considered of constant quality and composition. Beer viscosity, $\mu$, was measured by a Couette-type viscosimeter (Haake) and was found to be $3.1 \times 10^{-3}$ Pas at $0^{\circ} \mathrm{C}$.

A capillary pore polycarbonate membrane (Nuclepore, Schumacher DMF, Gonesse, France) was used of $0.2 \mu \mathrm{m}$ mean pore diameter, $9 \%$ surface porosity and $10 \mu \mathrm{m}$ thickness. A new membrane was used for each experiment. Membranes were rinsed before use by pumping Milli-Q water (Millipore Ltd, UK) through the membrane for one hour; water flux was reproducible and equal to $4200 \pm 250 \mathrm{~h} \mathrm{~h}^{-1} \mathrm{~m}^{-2}$ at $20^{\circ} \mathrm{C}$ and $P=100 \mathrm{kPa}$.

Some comparative measurements were made with a capillary pore aluminium oxide membrane (Anopore, Whatman International Ltd, Maidstone, UK) of $0.2 \mu \mathrm{m}$ mean pore diameter and $60 \mu \mathrm{m}$ thickness. Membrane porosity calculated from the water permeation rate was close to 0.5 . The use of capillary pore membranes with a narrow pore size distribution was appropriate to this study as it facilitates quantitative interpretation of data.

Transmembrane pressure $P$ was set either at 10 or at $100 \mathrm{kPa}$ for flux measurement with time, and either at 25 or at $100 \mathrm{kPa}$ for the additional measurement of protein retention with time. Stirring speed was constant at $850 \mathrm{rpm}$ (the corresponding impeller Reynolds number equals 1800 , i.e., the flow was in the laminar range) and filtration temperature was maintained at $0^{\circ} \mathrm{C}$ like the brewing separation process.

\section{Protein Adsorption Measurements}

For protein adsorption measurements, a PC membrane disk was held in the filtration cell holder. The filtration cell was filled with beer that was maintained at $0^{\circ} \mathrm{C}$. Adsorption took place under gently stirring the module without pressure so as to reach an adsorption equilibrium where diffusion is the sole solution transport process. Contact times ranged from 2 to 180 minutes. Beer retained inside the microporous structure of the membrane was then removed by swilling it with water. The amount of protein deposited on the membrane surface was determined by removal using a $1 \%$ sodium dodecyl sulphate solution and then measured by the modified Lowry method ${ }^{20}$. The amounts of protein present in the sample were calculated with a bovine serum albumin standardization curve, as reference.

\section{Beer Protein Assay Methods}

The determination of the protein concentration of beer in the course of the filtration was achieved by collecting samples $(1 \mathrm{ml})$ in the permeate side at regular time intervals (typically $5 \mathrm{~min}$ ). Samples were then analysed using two colorimetric methods, the Bradford ${ }^{21}$ and Lowry ${ }^{22}$ methods. The Bradford assay (based upon the binding of Coomassie Brillant Blue) was considered here as the reference method. Indeed, this one has been reported to be optimal for beer protein analysis because it is able to follow the variation of concentration of high molecular weight nitrogen compounds (MW > 5,000) in wort and beer and displays minimal interference ${ }^{23-25}$. Moreover the Bradford protein assay was found to give reproducible protein concentration values consistent with the protein content of beer as indicated by electrophoresis ${ }^{25}$. The protein content of the samples has been simultaneously monitored by the Lowry method based on the Biuret reaction; indeed this method may be considered as being complementary to the Bradford one, in that it is sensitive to nitrogen-containing compounds of lower molecular weight, i.e. peptides and amino acids (MW 1,500-5,000 $0^{26}$ ). However, the Lowry method is prone to interference from reducing substances and polyphenols present in beer ${ }^{23-25}$. 


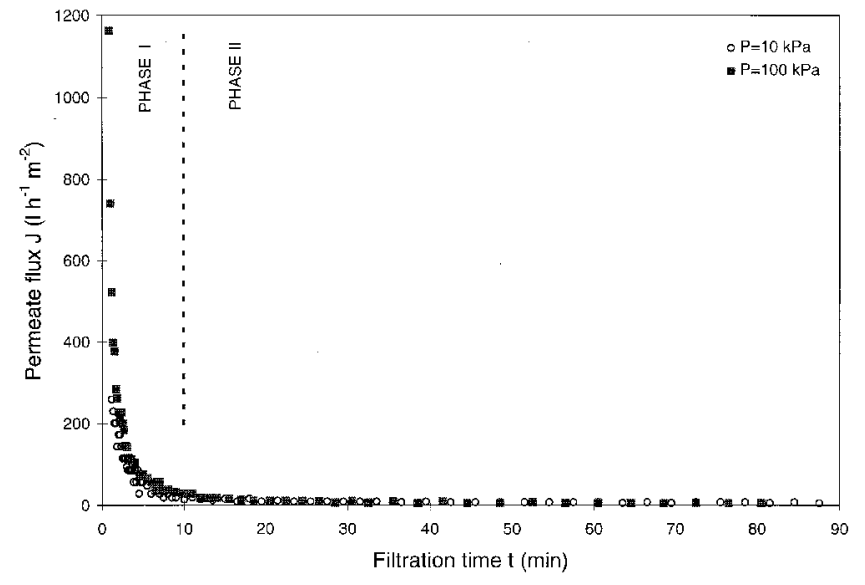

Figure 1. Variation of permeate flux $(J)$ with time $(t)$ under transmembrane pressures $P$ of 10 and $100 \mathrm{kPa}$ on a $0.2 \mu \mathrm{m}$ PC membrane. Experimental conditions: $850 \mathrm{rpm} ; 0^{\circ} \mathrm{C}$.

Beer proteins consist predominantly of barley albumins and globulins (MW 10,000-40,000) which are released into the wort and appear in small amounts $\left(20-600 \mathrm{mg}^{-1}\right)$ in the finished beer $^{25}$. In our experiments, the Bradford and Lowry methods gave protein concentration values in the retentate that ranged from 350 to $420 \mathrm{mg} \mathrm{ml}^{-1}$ and from 3.8 to $4.8 \mathrm{~g} \mathrm{l}^{-1}$, respectively. The reproducibility of the Bradford and Lowry assays for the determination of the protein content of beer was evaluated on the basis of protein assay of 25 aliquots of a pool of beers. The coefficient variations (CV) for the Bradford and Lowry assays were $3.2 \%$ and $4.1 \%$, respectively.

The protein retention is defined by:

$$
\text { Ret }=1-C_{p} / C_{0}
$$

where $C_{p}$ and $C_{0}$ are the protein concentration in permeate and retentate, respectively. It was verified that the protein concentration in the retentate varied very slightly in the course of the filtration for both protein assay methods so that it could be considered as being constant and equal to that of the feed solution $C_{0}$. The amounts of protein present in the sample were calculated with a bovine serum albumin standardization curve, as reference.

\section{RESULTS AND DISCUSSION \\ Variation of Permeate Flux and Protein Retention in the Course of the Filtration}

Variation of permeate flux with time

The rate of permeation $J$ during beer microfiltration through the PC membrane as a function of time at two applied pressures $P$ is shown in Figure 1. Such transmembrane pressures $(P=10$ and $100 \mathrm{kPa})$ were chosen because they correspond to the two domains of behaviour of the $J$ versus $P$ curves: pressure-dependent and -independent. Under the experimental conditions, permeate flux $J$ increased linearly with $P$ at low pressures, up to a critical or limiting pressure in the $70-90 \mathrm{kPa}$ range. Above 70 $90 \mathrm{kPa}, J$ was independent of transmembrane pressure. Hence in the pressure-independent region at $P=100 \mathrm{kPa}, J$ was controlled by mass transfer in the presence of a polarized layer at the solution-membrane interface while at $P=10 \mathrm{kPa}, J$ was controlled by the hydraulic membrane resistance. Also one transmembrane pressure is considered as high in beer CFMF (100 kPa) and the other as low $(10 \mathrm{kPa})^{15}$. For both transmembrane pressures there is a substantial flux decline as the process evolves, even though the pore diameter is much higher than the size of the macrosolutes in solution (see Table 1 that presents the list of the main macromolecular fractions in beer together with their range of concentration and molecular weight). All the filtration runs with the PC membrane have shown a characteristic profile as presented in Figure 1: a first phase (I in the Figure, $t<10 \mathrm{~min}$ ) in which the rate of flux decline is high, followed by a second one (II in the Figure, $t>10 \mathrm{~min}$ ) in which the rate of flux decline is lower (longterm fouling) and where permeate flux tends to a quasisteady value. It can be seen in Figure 1 that the initial rate of flux decline (over the phase I) increases with $P$. The quasisteady fluxes meet after 20 minutes of filtration (at $J \approx 10 \mathrm{lh}^{-1}$ $\mathrm{m}^{-2}$ ) which means that in terms of membrane resistance, the membrane is about tenfold more permeable at $10 \mathrm{kPa}$.

\section{Variation of protein retention $\left(\operatorname{Ret}_{B}, \operatorname{Ret}_{L}\right)$ with time}

For the whole filtration runs on PC membranes, the variation of protein retention with time (or filtered volume $V$ ) according to Bradford and Lowry methods (noted $\operatorname{Ret}_{B}$ and $\operatorname{Ret}_{L}$ respectively) has shown an identical and characteristic profile. This is presented in Figures 2(a) and 2(b) at $P=25 \mathrm{kPa}$ and $100 \mathrm{kPa}$, respectively. Three distinct phases can be distinguished independently of both protein assay method and applied transmembrane pressure: i) a first one for which Ret is constant at its lowest level, ii) a transition one characterized by a sudden increase (or protein retention step) and iii) a last one where Ret is stabilized and is at its highest level. For each filtration run, it appeared that the protein retention step occurred at a same filtrate volume (noted $V_{B}{ }^{*}$ and $V_{L} *$ for Bradford and Lowry methods, respectively) which in addition varied slightly with runs and pressure $\left(V_{B} *\right.$ and $V_{L} *$ ranged from 40 to $50 \mathrm{ml}$ as seen in Figures 2(a) and 2(b)). The final constant retention level, at

Table 1. Main macromolecular fractions present in $\operatorname{beer}^{26}$.

\begin{tabular}{lcc}
\hline Molecular fraction & Concentration $\left(\mathrm{gl}^{-1}\right)$ & Molecular weight $\mathrm{MW}\left(\mathrm{g} \mathrm{mol}^{-1}\right)$ \\
\hline Dextrins & $25-35$ & $50,000-200,000$ \\
$\beta$-glucans & $0.07-0.5$ & $50,000-200,000$ \\
Pentosans & $1.5-3.5$ & $50,000-200,000$ \\
Proteoses ${ }^{*}$, albumoses, peptones & $0.06-0.2$ & $5,000-70,000$ \\
Peptides & $0.1-0.5$ & $1,500-5,000$ \\
Amino acids & $0.02-0.1$ & $<5,000$ \\
Polyphenols & $0.02-0.06$ & $1,000-5,000$ \\
\hline
\end{tabular}

\footnotetext{
*Amino-acid complexes coupled with non-nitrogenous substances.
} 


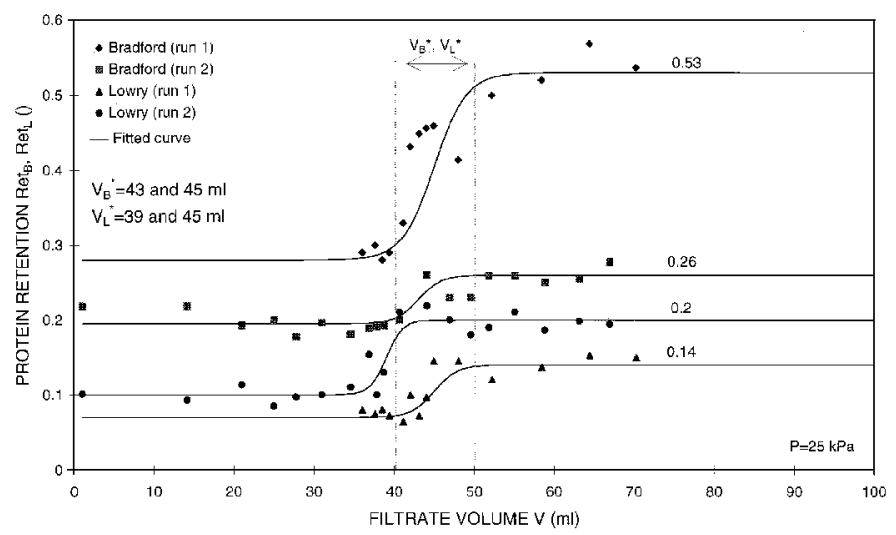

Figure 2. (a) Variation of protein retention $\left(\operatorname{Ret}_{B}, \operatorname{Ret}_{L}\right)$ with filtered volume $(V)$ for two filtration runs on a $0.2 \mu \mathrm{m}$ PC membrane. Experimental conditions: $P=25 \mathrm{kPa} ; 850 \mathrm{rpm} ; 0^{\circ} \mathrm{C}$.

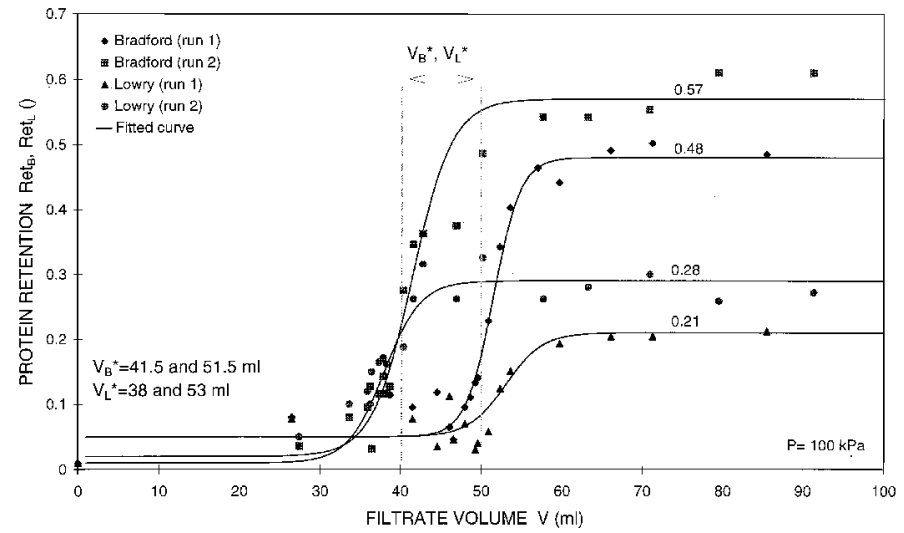

Figure 2. (b) Variation of protein retention $\left(\operatorname{Ret}_{B}, \operatorname{Ret}_{L}\right)$ with filtered volume $(V)$ for two filtration runs on a $0.2 \mu \mathrm{m}$ PC membrane. Experimental conditions: $P=100 \mathrm{kPa} ; 850 \mathrm{rpm} ; 0^{\circ} \mathrm{C}$.

a given applied pressure, was systematically higher for the Bradford method (e.g. it is two times higher at $P=100 \mathrm{kPa}$ in Figure 2(b)); this may be expected as the Bradford method (contrary to the Lowry one) is sensitive to proteins or polypeptides of approximately $\geq 4,000-5,000^{23}$ molecular weight. Protein retention step increment for a given assay method was found to increase with pressure so that in most cases the final protein retention, associated with the quasisteady permeate flux, increased with pressure.

The observation of a retention step increment occurring over a narrow range of the filtrate volume $\left(40<V_{B}{ }^{*}, V_{L}{ }^{*}<50 \mathrm{ml}\right.$, see Figures 2(a) and 2(b)) suggests that the sharp retention increase happens when a certain quantity of matter is deposited inside the membrane. This will be further confirmed with the fitting to the standard blocking filtration law of the total membrane resistance increase at the early stages of filtration.

Flux decline (Figure 1) and protein retention (Figures 2(a) and 2(b)) show profiles which are characteristic of fouling permeant species with partially-permeable membranes that modify both flux and rejection ${ }^{27}$. Similar profiles have been obtained in the ultrafiltration of a protein solution, in the case of an ultrafiltration membrane partially permeable to lysosyme and an ultrafiltration membrane permeable to bovine serum albumin ${ }^{27}$. In both cases the characteristic profiles have been interpreted by an initial internal fouling of the membrane followed by the formation of a solute-membrane 'composite' with rejection (and flux) characteristics substantially different from the primary membrane. It will be shown further that such mechanisms also take place during cold sterile microfiltration of beer for which $98-99 \%$ of the solutes ${ }^{26}$ (measured on dry weight basis) are transported through the membrane pore phase.

The dependence of protein retention on filtered volume for an $\mathrm{Al}_{2} \mathrm{O}_{3}$ membrane was compared to that for the PC membrane under identical operating conditions. Figure 3 shows the variation of both $\operatorname{Ret}_{B}$ and $\operatorname{Ret}_{L}$ with $V$ throughout one run at two applied pressures. It clearly appears that the $\mathrm{Al}_{2} \mathrm{O}_{3}$ membrane exhibits a characteristic retention profile which is very similar to that of the PC membrane (see Figures 2(a) and 2(b)). The three distinct phases described above in the course of the filtration are again present. Moreover, the protein retention step increment increases with pressure so that the final protein retention level is higher at $100 \mathrm{kPa}$, as it was found for the PC membrane.

Thus the mechanisms of protein transmission through the pore phase are close for both membrane types, although they have different physical properties $\left(\mathrm{Al}_{2} \mathrm{O}_{3}\right.$ membrane is hydrophilic and has a far larger surface porosity). It should be noted that for a given applied pressure the filtrate volume at which protein retention step occurs (i.e. $V_{B}{ }^{*}$ and $V_{L}{ }^{*}$ ) is 


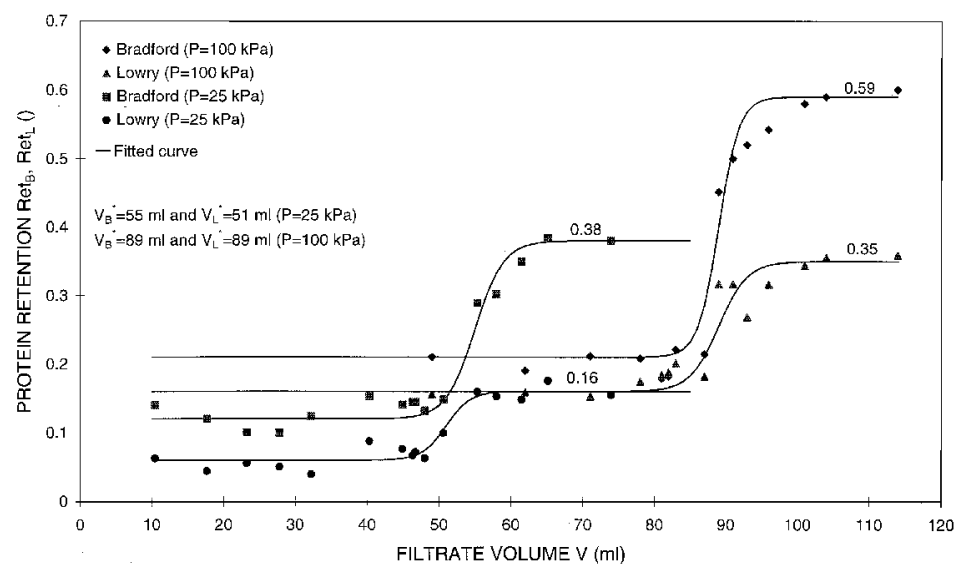

Figure 3. Variation of protein retention $\left(\operatorname{Ret}_{B}, \operatorname{Ret}_{L}\right)$ with filtered volume $(V)$ on a $0.2 \mu \mathrm{m} \mathrm{Al} \mathrm{O}_{3}$ membrane. Experimental conditions: $P=25 \mathrm{kPa}$ and $100 \mathrm{kPa}$; $850 \mathrm{rpm} ; 0^{\circ} \mathrm{C}$.

significantly higher for the $\mathrm{Al}_{2} \mathrm{O}_{3}$ membrane (see Figures 2(a), 2(b) and 3). This is discussed further.

\section{Fouling Mechanisms}

Blocking filtration law analysis

Experimental data have been tested with the linearized forms of blocking filtration laws presented in the Appendix (equations (3), (6), (10) and (14)). The minimum coefficient of linear regression $R^{2}$ has been sought either on the whole duration of the run or part of it. It has been found that for all runs, experimental data on the $\mathrm{PC}$ membrane support the standard blocking law (SBL) and the cake filtration law (CFL). Typical results of data analysis are presented in Figures 4(a), 4(b), 5(a) and 5(b) at $P=10$ and $100 \mathrm{kPa}$, respectively. First filtration conforms to SBL (for $2.4<t$

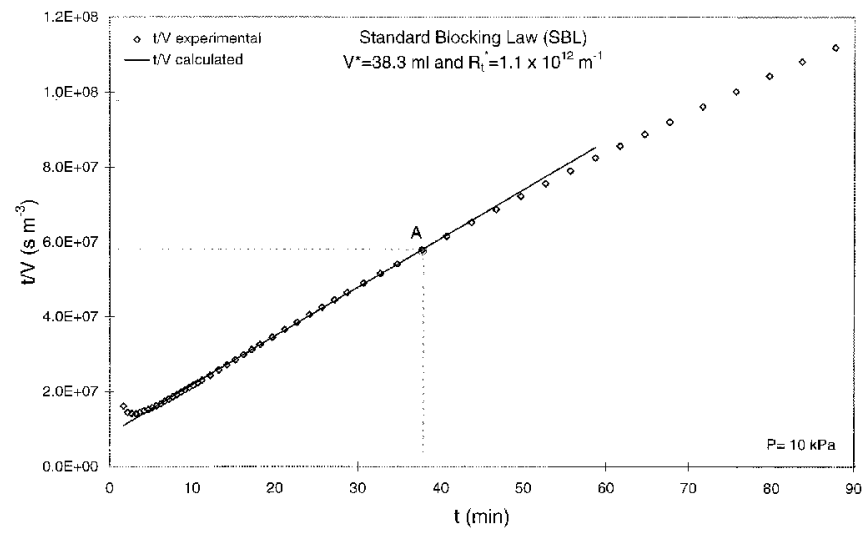

Figure 4. (a) SBL plots for beer microfiltration on a $0.2 \mu \mathrm{m}$ PC membrane. Experimental conditions: $P=10 \mathrm{kPa} ; 850 \mathrm{rpm} ; 0{ }^{\circ} \mathrm{C}$.

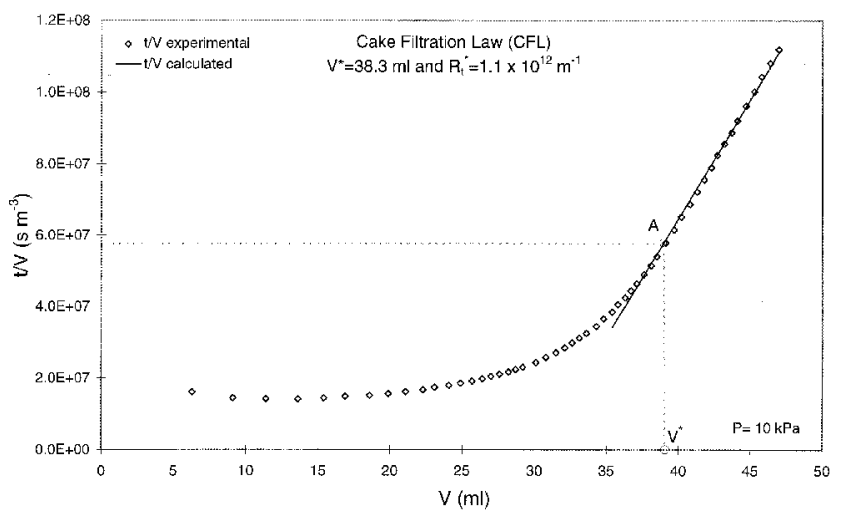

Figure 4. (b) CFL plots for beer microfiltration on a $0.2 \mu \mathrm{m}$ PC membrane. Experimental conditions : $P=10 \mathrm{kPa} ; 850 \mathrm{rpm} ; 0^{\circ} \mathrm{C}$. 


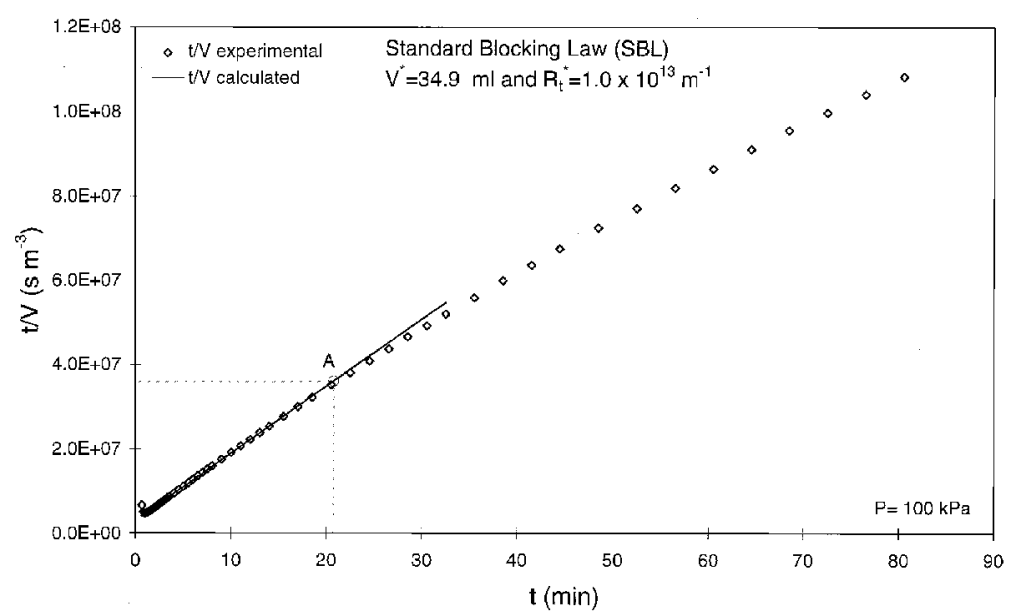

Figure 5. (a) SBL plots for beer microfiltration on a $0.2 \mu \mathrm{m}$ PC membrane. Experimental conditions: $P=100 \mathrm{kPa} ; 850 \mathrm{rpm} ; 0^{\circ} \mathrm{C}$.

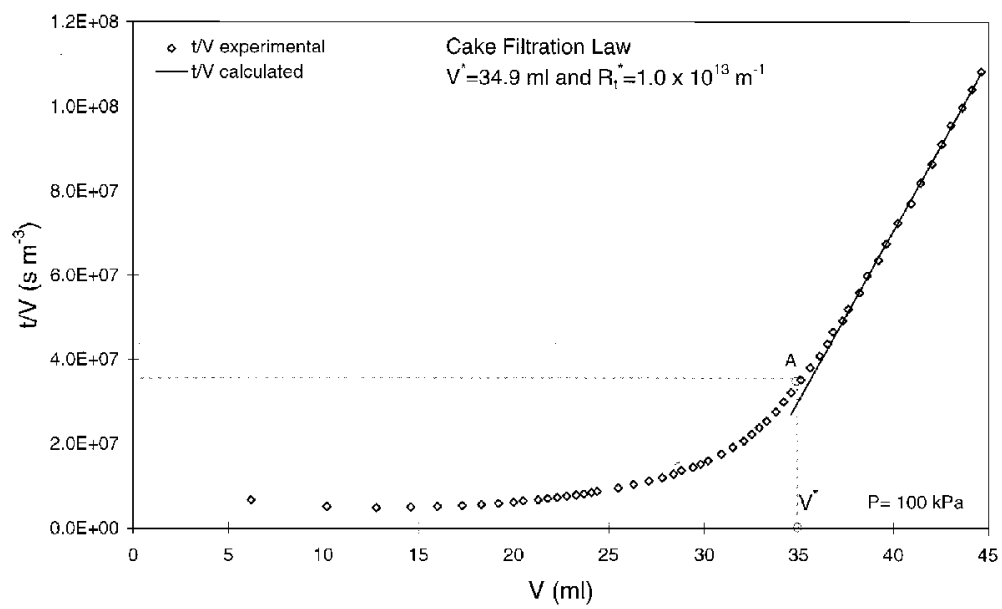

Figure 5. (b) CFL SBL plots for beer microfiltration on a $0.2 \mu \mathrm{m}$ PC membrane. Experimental conditions: $P=100 \mathrm{kPa} ; 850 \mathrm{rpm} ; 0^{\circ} \mathrm{C}$.

$<38 \mathrm{~min}$ at $10 \mathrm{kPa}$ and $0.2<t<20 \mathrm{~min}$ at $100 \mathrm{kPa}$ for the whole filtration runs), then CFL applies up to the end of the run. As can be seen from the figures, the end of the SBL period corresponds to the beginning of the CFL application (transition point A on the figures). This reveals the transition from an initial internal clogging of membrane pores to the build-up of an external fouling layer over the membrane surface. The transition from SBL to CFL is consistent with the shape of the flux versus time curves in Figure 1. The sharp rate of flux decline at the early stages of the filtration (phase I) may be related to that predicted by $\mathrm{SBL}^{18}$, i.e. $J / J_{0}=(1+a t)^{-2}$, and the long-term fouling rate (phase II) to that predicted by $\mathrm{CFL}^{18}$, i.e. $J / J_{0}=(1+a t)^{-0.5}$.

A deviation from the linear relation between $t / V$ and $t$ may be noted at the initial stages of the filtration $(0-4 \mathrm{~min})$ in Figure 4(a) at low applied pressure conditions, which is less pronounced at high pressure in Figure 5(a) (0-1 min). A possible explanation for this phenomenon is that in these early stages under low applied pressure, only a small filtrate volume passes through the membrane pores. The specific surface area and the permeability of the membrane being large, macrosolutes penetrate and are adsorbed within it. Under such experimental conditions, solute adsorption prevails (involving strictly an equilibrium process with partitioning of solute between a solution and a surface) and
SBL is not the predominant solute retention mechanism. Indeed SBL implicitly assumes a convection-induced deposition, essentially a solute-solute interaction induced by flow through the micropores of the membrane. Filtration at high pressure results in a much higher filtrate volume in the first few minutes of the filtration and faster decrease of pore/solute size ratio. For this reason the extent of deviation of the SBL application at the early stage of filtration is insignificant.

\section{Fouling parameters evaluated from the blocking filtration law analysis}

For the various experiments the fouling parameters $C$ (vol/vol) and $\alpha C_{b}\left(\mathrm{~m}^{-2}\right)$ related to SBL and CFL have been calculated from the linear $t / V$ vs $t$ (equation (10)) and $t /$ $V$ vs $V$ (equation (14)) plots, respectively. The parameters $C$ and $\alpha C_{b}$ characterize the potential of the solution for internal and external (surface) fouling, respectively.

For the cake filtration law, the specific resistance of the cake layer $\left(\alpha\right.$ in $\left.\mathrm{m} \mathrm{kg}^{-1}\right)$ cannot be evaluated in this case since the actual concentration of the solutes which deposit on the membrane surface $\left(C_{b}\right)$ is unknown, due to the large variety of potential foulant species present in beer. The term $\alpha C_{b}$ is equal to the product of the specific deposit resistance $\alpha$ (the resistance of a layer of unit mass deposited per unit 
area, concept introduced by Chudacek and Fane ${ }^{28}$ ) by the feed concentration of the solutes that are retained by a sieving effect over the CFL period. The solutes involved in the surface fouling layer in the sterilizing microfiltration of a clarified beer are high molecular weight macrosolutes (see Table 1) and colloids (complex molecules resulting from the reaction of proteins with polyphenols, together with heavy metals, dextrins and $\beta$-glucans ${ }^{29}$ ). As the beer was supplied from the same brewery, its quality and composition were constant and the concentration $C_{b}$ of macromolecules and colloids which were retained by a sieving effect over the CFL period could be reasonably considered as being constant. This hypothesis was strengthened by the measurement of a dry matter retention which varied slightly between the membrane fouling runs (i.e. for which the rate of permeation was measured throughout the filtration as a function of time in the absence of permeate sampling). It can be assumed that the totality of the solutes responsible for the loss of dry matter are retained by a sieving effect over the CFL period (this was verified for proteins for which rejection increases sharply once CFL occurs). The dry matter content of the samples was measured according to the standard method recommended for beer solutions ${ }^{19}$. Dry matter retention was found to vary slightly from one run to another with an average value $\operatorname{Ret}=0.08 \pm 0.011$. Therefore the term $\alpha C_{b}$, like $\alpha$, is representative of the hydraulic resistance of the cake layer deposited on the membrane surface, provided that $C_{b}$ is constant.

The values of $C$ and $\alpha C_{b}$ are summarized in Table 2. It can be seen in Table 2 that the values of $C$ vary between $2.6 \times 10^{-5}$ to $8 \times 10^{-5} \mathrm{vol} / \mathrm{vol}$ and that they tend to increase with $P$. Such values are close to those reported in beer microfiltration through a $0.2 \mu \mathrm{m}$ capillary pore polyethylene-terephtalate (PET) membrane ${ }^{15}$. In the latter case, the average values of $C$ were $2.7 \times 10^{-5}$ at $10 \mathrm{kPa}$ and $1.3 \times 10^{-4}$ at $100 \mathrm{kPa}$. This indicates that the amount of solutes deposited onto the pore wall per unit filtrate volume is similar for a PC and PET membrane and that the same molecular fractions are possibly involved in this process.

The values of $C$ determined under given operating conditions allow some insight into the foulant species responsible for the initial sharp flux decline. Assuming that the solutes deposited onto the pore wall have a specific mass of $1 \mathrm{~g} \mathrm{~cm}^{-3}$, it is found that their concentration in beer ranges from 0.025 to $0.08 \mathrm{~g}^{-1}$. Table 1 presents the

Table 2. Calculated values of the fouling parameters $C$ (standard blocking law) and $\alpha \mathrm{C}_{b}$ (cake filtration law) for the various experimental conditions with a $0.2 \mu \mathrm{m}$ PC membrane.

\begin{tabular}{lcc}
\hline $\begin{array}{l}\text { Transmembrane } \\
\text { pressure } \mathrm{P}(\mathrm{kPa})\end{array}$ & $\begin{array}{c}\mathrm{C}(\mathrm{vol} / \mathrm{vol})\left(+-\mathrm{SE}^{\mathrm{a}}\right) \\
\left(\times 10^{5}\right)\end{array}$ & $\begin{array}{c}\alpha \mathrm{C}_{b}\left(+-\mathrm{SE}^{\mathrm{a}}\right) \\
\left(\times 10^{-14}\right)\end{array}$ \\
\hline 10 & $2.73(+-0.024)$ & $0.838(+-0.0049)$ \\
& $2.71(+-0.019)$ & $0.856(+-0.0057)$ \\
& $2.56(+-0.018)$ & $0.837(+-0.0086)$ \\
100 & $2.98(+-0.084)$ & $1.10(+-0.007)$ \\
& $2.89(+-0.03)$ & $1.92(+-0.022)$ \\
& $5.90(+-0.076)$ & $12.6(+-0.057)$ \\
200 & $3.11(+-0.0095)$ & $8.57(+-0.056)$ \\
& $7.97(+-0.15)$ & $9.68(+-0.1)$ \\
& $4.12(+-0.032)$ & $19.9(+-0.89)$ \\
\hline
\end{tabular}

${ }^{a}$ Standard error. molecular fractions of beer components of high molecular weight which were reported as being specific foulants in the adsorption/deposition inside pore phase during beer $\mathrm{CFMF}^{26}$. Considering the variation range of the concentration of the various molecular fractions in Table 1, it is suggested that progressive pore plugging may arise from high MW macromolecules such as $\beta$-glucans, pentosans, polyphenols and proteins. In particular, proteins and peptides are likely to play an important role in pore plugging because they are present in large concentrations $\left(0.06-0.5 \mathrm{~g}^{-1}\right)$ and have a great tendency to adsorb on membrane material as it will be shown further. The Stokes radius $\left(r_{s}\right)$ of proteins may be evaluated using the equation proposed by Loret et al. ${ }^{30}$ :

$$
\begin{aligned}
r_{s}(\mathrm{~nm})= & 13.7198-7.6947(\log \mathrm{MW}) \\
& +1.1928(\log \mathrm{MW})^{2}-0.00717(\log \mathrm{MW})^{3}
\end{aligned}
$$

where $\mathrm{MW}$ is the protein molecular weight in $\mathrm{g} \mathrm{mol}^{-1}$.

Using equation (15), the diameters of proteins with a MW ranging from 5,000 to 70,000 are respectively 0.0024 and $0.0072 \mu \mathrm{m}$. Considering a monolayer protein coverage on the internal wall of a $0.2 \mu \mathrm{m}$ diameter pore, one calculates that its section would decrease from 5 to $14 \%$. Therefore the strong flux reduction experimentally observed over the SBL period may be explained by the deposition inside the membrane of macrosolutes of high MW like proteins, $\beta$-glucans and pentosans (pentosans especially were found to be a major factor in pore blocking by in-depth adsorption/deposition on ceramic membranes ${ }^{14}$ ).

Table 2 shows that the values of the fouling parameter for the cake filtration law, $\alpha C_{b}$, increased with $P$. It is about tenfold higher at $100 \mathrm{kPa}$ than at $10 \mathrm{kPa}$ indicating that the hydraulic resistance of the cake (or gel) layer formed at the membrane surface is much more permeable at low applied pressure. This result is in agreement with the observation of a total membrane resistance $R_{t}$ in the quasi-steady state flux phase which is about ten times larger at $100 \mathrm{kPa}$ (see phase II in Figure 1). It shows that over the CFL period the permeate flux is governed by the hydraulic resistance of an external and compressible fouling layer. The effect of pressure on $\alpha$ is frequently expressed by the relationship ${ }^{28}$,

$$
\alpha=\alpha_{0} P^{m}
$$

where $m$ is the compressibility factor. The calculated value of $m$ using equation (16) for the values of $\alpha C_{b}$ presented in Table 2 is $m=1.04 \pm 0.04$. This indicates that the surface fouling layer is highly compressible when compared with typical values of 0.2 to 0.7 for compressible solids ${ }^{31}$.

\section{Membrane pore diameter decrease due to protein adsorp- tion and solute deposition onto the pore wall over the $S B L$ period \\ The effects of protein adsorption on pore diameter decrease \\ The constant and low level of protein retention in the presence of a pore diameter decrease conforming to SBL at the early stages of the filtration (see Figures 2(a) and 2(b)) indicates that protein-membrane interactions take place in the form of protein adsorption/deposition. In order to characterize the role played by protein-membrane inter- actions in internal membrane fouling, the amount of protein}




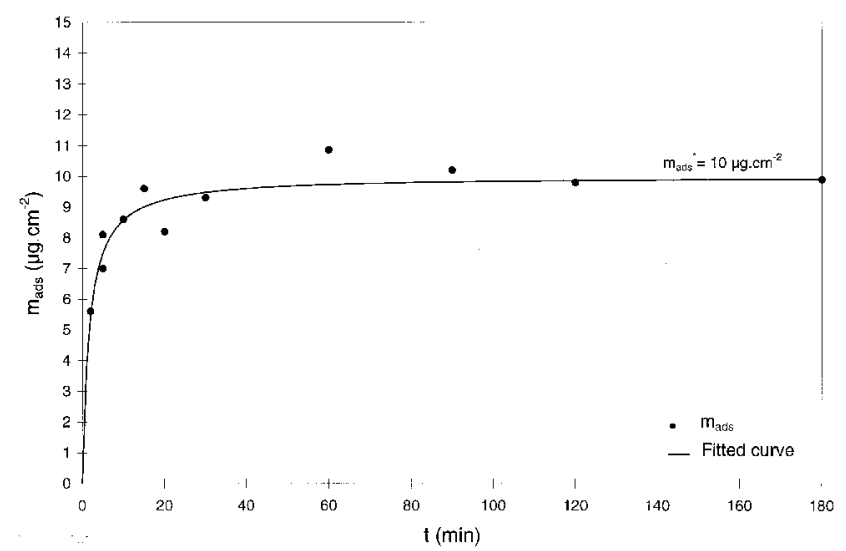

Figure 6. Variation of the amount of protein adsorbed per unit filter membrane area with time on a $0.2 \mu \mathrm{m}$ PC membrane. Experimental conditions: gentle stirring; $0^{\circ} \mathrm{C} ; P=0 \mathrm{kPa}$.

adsorbed on the membrane $\left(m_{a d s}\right.$ in $\left.\mu \mathrm{g} \mathrm{cm}^{-2}\right)$ was measured as a function of time. Figure 6 shows the variation of the quantity of adsorbed protein with time. The amount of adsorbed protein increases sharply at contact times lower than 10 minutes and then reaches a plateau at about $10 \mu \mathrm{g} \mathrm{cm}^{-2}$. This is consistent with the amount of adsorbed protein $\left(3-20 \mu \mathrm{g} . \mathrm{cm}^{-2}\right)$ reported on a polyethyleneterephtalate microfiltration membrane using the same experimental procedure with a commercial Lager beer ${ }^{15}$.

The shape of the curve in Figure 6 suggests that a full monolayer of adsorbed protein is achieved at $t>20 \mathrm{~min}$ (as predicted from a Langmuir type isotherm). The corresponding protein monolayer capacity (in $\mathrm{mg} \mathrm{m}^{-2}$ ) on the membrane is given by,

$$
a_{m}=10\left(m_{a d s}^{*} / S_{s p}\right)
$$

where $m_{a d s}^{*}$ is the adsorbed protein mass at the plateau per unit membrane surface area (i.e. $10 \mu \mathrm{g} . \mathrm{cm}^{-2}$ ) and $S_{s p}$ the specific surface area of the membrane (total surface area/ membrane surface area, dimensionless). With $S_{s p}=20.7$ for the $0.2 \mu \mathrm{m}$ PC membrane, the protein monolayer capacity $a_{m}$ is equal to $4.8 \mathrm{mg} \mathrm{m}^{-2}$. Such a value is close to the amount of adsorbed protein $\left(3.41 \pm 0.47 \mathrm{mg} \mathrm{m}^{-2}\right)$ reported on the surface of a tubular ceramic membrane with a nominal pore size of $0.5 \mu \mathrm{m}$ using the standard Bradford protein assay method ${ }^{16}$. Moreover the measured protein monolayer capacity corresponds roughly to the theoretical bovine serum albumin monolayer capacity in side-on orientation $^{32}\left(2.5 \mathrm{mg} \mathrm{m}^{-2}\right)$. This suggests that at the initial stages of the filtration when protein-membrane interactions prevail, the rate of flux decline arises, at least in part, from a pore diameter reduction induced by the build-up of a protein monolayer inside pore phase.

The membrane pore diameter decrease due to protein adsorption (at equilibrium adsorption) and the resulting loss of membrane permeability can be derived from the amount of protein adsorbed at the plateau in Figure 6. The membrane pore diameter decrease due to protein adsorption is given by,

$$
\Delta d_{a d s}=2 \delta_{a d s}=2 m_{a d s}^{*} /\left(\rho_{s} S_{s p}\right)
$$

where $\rho_{s}$ is the specific mass of proteins $\left(\mathrm{kg} \mathrm{m}^{-3}\right)$. The percentage of membrane permeability decrease is expressed as:

$$
\frac{L_{p}-L_{p 0}}{L_{p 0}}=100\left[1-\left(1-\frac{\Delta d_{a d s}}{d_{0}}\right)^{4}\right]
$$

Assuming proteins have a specific mass of $1000 \mathrm{~kg} \mathrm{~m}^{-3}$, we calculate from equations (19) and (20) $\Delta d_{a d s}=10 \mathrm{~nm}$ $\left(\delta_{a d s}=5 \mathrm{~nm}\right)$ and a membrane permeability decrease of $18.5 \%$, respectively. These values will be compared in the next section to those determined at the beginning of SBL applicability when solute-membrane interactions are thought to prevail at short filtration times $(0-5 \mathrm{~min})$.

The effects of solute deposition onto the pore wall over the SBL period on pore diameter decrease

The central feature of the standard blocking law is a progressive build-up of a deposited layer of solutes on the pore walls. It enables the thickness of the layer formed as well as the membrane permeability decrease under the various experimental conditions to be evaluated. Table 3 summarizes the calculated values of the mean pore diameter decrease $(\Delta d)$ and thickness of the layer deposited onto the pore wall $(\delta)$ at the beginning and at the end of the SBL period with the corresponding membrane permeability decrease for the various experiments on the $0.2 \mu \mathrm{m}$ PC membrane.

At the beginning of the SBL period, the mean pore diameter decrease can be expressed as:

$$
\Delta d=d_{0}\left(1-\left(\frac{R_{t 0}}{R_{t}}\right)^{0.25}\right)
$$

where $R_{t}$ is the total membrane resistance at the beginning of the SBL period and $R_{t 0}$ the initial membrane resistance.

Over the SBL period, the effective membrane pore radius at the end of the SBL period may be calculated from:

$$
r=\left[r_{0}^{2}-\frac{C V}{n^{*} S \pi L}\right]^{0.5}
$$

where $r_{0}$ is the initial membrane pore radius, $n^{*}$ the number of pores per unit membrane surface area (i.e. $3 \times 10^{12} \mathrm{~m}^{-2}$ on an average for the PC membrane according to the manufacturer), $S$ the membrane surface area $\left(0.00125 \mathrm{~m}^{2}\right)$ and $V$ the cumulative filtrate volume over the SBL period. Using the value of $r$ derived from equation (22), the mean pore diameter decrease at the end of the SBL period is then given by,

$$
\Delta d=2\left(r_{0}-r\right)
$$

It can be seen from Table 3 that the mean pore diameter decrease at the beginning of the SBL period $\left(3<\Delta d^{n}<10 \mathrm{~nm}\right)$ is low in comparison with the nominal pore size of the membrane $d_{0}(200 \mathrm{~nm})$. In addition, $\Delta d^{a}$ does not depend on transmembrane pressure as it would have been expected because at this stage solute-membrane interactions (interfacial phenomena) are predominant. Indeed, $\Delta d^{a}$ takes place at the very early stages of the filtration (with $2.4<t<5 \mathrm{~min}$ at $10 \mathrm{kPa}$ and $0.2<t<1.2 \mathrm{~min}$ at $100 \mathrm{kPa}$ ). If the corresponding values of the thickness of the layer formed (i.e. $1.5<\delta^{a}<6 \mathrm{~nm}$ in Table 3) are compared with those experimentally determined for protein adsorption (i.e. $\delta_{a d s} \approx 5 \mathrm{~nm}$ at the plateau of Figure 6), it clearly appears that they are close. 
Table 3. Calculated values of the mean pore diameter decrease $(\Delta d)$ and thickness of the layer deposited onto the pore wall $(\delta)$ at the beginning and at the end of the SBL period with the corresponding membrane permeability decrease $\left(L_{p}-L_{p 0} / L_{p 0}\right)$ for the various experiments on a $0.2 \mu \mathrm{m}$ PC membrane.

\begin{tabular}{|c|c|c|c|c|c|c|}
\hline $\begin{array}{l}\text { Transmembrane } \\
\text { pressure } \mathrm{P}(\mathrm{kPa})\end{array}$ & $\begin{array}{l}\Delta d^{\mathrm{a}} \\
(\mu \mathrm{m})\end{array}$ & $\begin{array}{c}\delta^{\mathrm{a}} \\
(\mathrm{nm})\end{array}$ & $\begin{array}{c}\left(L_{p}-L_{p 0} / L_{p 0}\right) \\
\quad \times 100^{\mathrm{a}}(\%)\end{array}$ & $\begin{array}{l}\Delta d^{\mathrm{b}} \\
(\mu \mathrm{m})\end{array}$ & $\begin{array}{c}\delta^{\mathrm{b}} \\
(\mathrm{nm})\end{array}$ & $\begin{array}{l}\left(L_{p}-L_{p 0} / L_{p 0}\right) \\
\quad \times 100^{\mathrm{b}}(\%)\end{array}$ \\
\hline 10 & $\begin{array}{l}0.0085 \\
0.0095 \\
0.003 \\
0.003\end{array}$ & $\begin{array}{l}4.3 \\
4.8 \\
1.5 \\
1.5\end{array}$ & $\begin{array}{r}15.9 \\
17.7 \\
5.9 \\
5.9\end{array}$ & $\begin{array}{l}0.055 \\
0.050 \\
0.052 \\
0.048\end{array}$ & $\begin{array}{l}27.5 \\
25 \\
26 \\
24\end{array}$ & $\begin{array}{l}72.4 \\
68.3 \\
70.0 \\
66.6\end{array}$ \\
\hline 100 & $\begin{array}{l}0.003 \\
0.0071 \\
0.0054 \\
0.0036\end{array}$ & $\begin{array}{l}1.5 \\
3.5 \\
2.7 \\
1.8\end{array}$ & $\begin{array}{r}5.9 \\
13.5 \\
10.4 \\
7.0\end{array}$ & $\begin{array}{l}0.085 \\
0.1 \\
0.062 \\
0.065\end{array}$ & $\begin{array}{l}42.5 \\
50 \\
31 \\
32\end{array}$ & $\begin{array}{l}89.1 \\
93.8 \\
77.3 \\
79.2\end{array}$ \\
\hline 200 & 0.0053 & 2.7 & 10.6 & 0.11 & 55 & 95.9 \\
\hline
\end{tabular}

a At the beginning of the SBL period.
b At the end of the SBL period.

This indicates that proteins (protein-carbohydrates associations as many of the beer proteins are glycosylated ${ }^{25}$ ) are likely to be the main molecular fraction that adsorbs on membrane material at the early stages of the filtration with a hydrophobic organic membrane. Under the given experimental conditions, this phenomenon results in a membrane permeability decrease of $10-20 \%$.

Membrane pore diameter decrease at the end of the SBL period $\left(\Delta d^{b}\right.$ in Table 3$)$ at the two applied pressures is one order of magnitude larger than that at the beginning of the SBL period ( $\Delta d^{a}$ in Table 3$)$. Progressive pore plugging over the SBL period leads to a significant loss of membrane permeability ranging from $66-72 \%$ at $10 \mathrm{kPa}$ and up to $95 \%$ at 100 and $200 \mathrm{kPa} . \Delta d^{b}$ increases gradually with pressure with values ranging from $48-55 \mathrm{~nm}$ to $62-100 \mathrm{~nm}$ at 10 and $100 \mathrm{kPa}$, respectively. Solute deposition over the SBL period, essentially a solute-solute interaction induced by flow through the membrane pores, is thus far greater than solute adsorption when the feed solution is brought into contact with the membrane material at the initial stages of the filtration $(0-5 \mathrm{~min})$. The increase of the thickness of the layer formed with the applied pressure may be related to the larger values of the fouling parameter $\mathrm{C}$ at high pressure (see Table 2). This indicates that internal membrane fouling is promoted by shear in the pores. At large transmembrane pressures, initial flux is high and macrosolutes and colloids flowing through the membrane pores are subjected to significant shear stresses (typically wall shear stress is $18 \mathrm{~Pa}$ at $P=10 \mathrm{kPa}$ and up to $140 \mathrm{~Pa}$ at $P=100 \mathrm{kPa}$ ). As a comparison, the shear force in a concentric viscosimeter, which is the most commonly used apparatus for generating high shear forces, reaches values up to $25 \mathrm{kPa}$. An identical increase of internal membrane fouling with the applied pressure has been reported in the microfiltration of proteins $^{33,34}$ and colloids ${ }^{35}$.

\section{Relationship Between Fouling Mechanism and Protein Retention}

From the investigation of protein retention and fouling mechanism throughout the microfiltration of a clarified beer, it is shown that: (i) protein retention is characterized by a protein retention step that occurs in a narrow variation range of filtrate volume and (ii) fouling mechanism has been interpreted as the transition from an initial internal clogging of membrane pores (SBL) to the build-up of an external fouling layer over the membrane surface (CFL).

It turned out that the SBL-CFL transition could be linked with the protein retention step. For this purpose, two filtration parameters $\left(R_{t}^{*}\right.$ and $\left.V^{*}\right)$ are defined in relation to the SBL-CFL transition as well as two parameters $\left(V_{B}{ }^{*}\right.$ and $\left.V_{L}{ }^{*}\right)$ in relation to the protein retention step for Bradford and Lowry methods.

\section{Characterization of the SBL-CFL transition via the filtration parameters $R_{t}^{*}$ and $V^{*}$}

The two filtration parameters $R_{t}^{*}$ and $V^{*}$ have been determined from the blocking filtration law analysis using a convenient general mathematical form. For constantpressure filtration, blocking filtration laws can be written in a general form describing the variation of $R_{t}$ with $t$ as follows ${ }^{18}$ :

$$
R_{t}=R_{t 0}(1+\mathrm{at})^{n}
$$

where $n$ is a parameter depending on filtration law ( $n=2$ for SBL and $n=0.5$ for CFL) and $a$ is a fouling coefficient depending on filtration law.

For the whole fouling filtration runs on $\mathrm{PC}$ and $\mathrm{Al}_{2} \mathrm{O}_{3}$ membranes, the $\log \left(R_{t}\right)$ vs $\log (t)$ curves were found to vary linearly with two distinct slopes $\mathrm{n}$ equal to 2 and 0.5 . It was verified that the change of slope for the $\log \left(R_{t}\right)$ vs $\log (t)$ curves was located at the transition point A (see Figures 4(a), 4(b) and 5(a), 5(b)) determined elsewhere from the $t / V$ vs $t$ and $t / V$ vs $t$ curves. A representative example of the $\log \left(R_{t}\right)$ vs $\log (t)$ curves obtained on a PC membrane is presented in Figure 6 for two experiments at $10 \mathrm{kPa}$ and two ones $100 \mathrm{kPa}$. It is seen in Figure 6 that the SBL-CFL transition can be easily determined at the change of slope from $n=2$ to $n=0.5$ (transition point $\mathrm{A}$ ).

Using equation (24), the transition from SBL to CFL has been thus characterized by the parameters $R_{t}^{*}$ and $V^{*}$ representing respectively the membrane resistance and the filtered volume at the point of intersection of the two straight $\operatorname{lines} \log \left(R_{t}\right)$ versus $\log (t)$ of initial slope close to 2 and final slope close to 0.5 (as shown in Figure 7). Table 4 summarizes the calculated values of $R_{t}^{*}$ and $V^{*}$ for the various membrane fouling runs at $P=10$ and $100 \mathrm{kPa}$. It is noticed in Table 4 that for most of the runs, $V^{*}$ lies in a narrow variation range $\left(32<V^{*}<39 \mathrm{ml}\right)$ which is systematically located upstream the corresponding variation range 


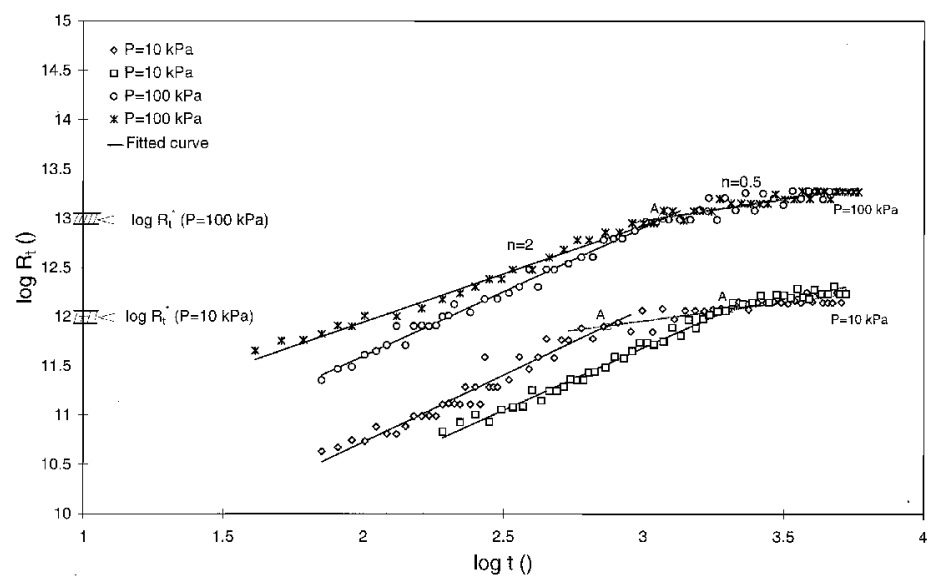

Figure 7. Transition from SBL to CFL for beer microfiltration on a $0.2 \mu \mathrm{m}$ PC membrane: $\log \left(R_{t}\right)$ versus $\log (t)$ curves. Experimental conditions: $P=10$ and $100 \mathrm{kPa} ; 850 \mathrm{rpm} ; 0^{\circ} \mathrm{C}$.

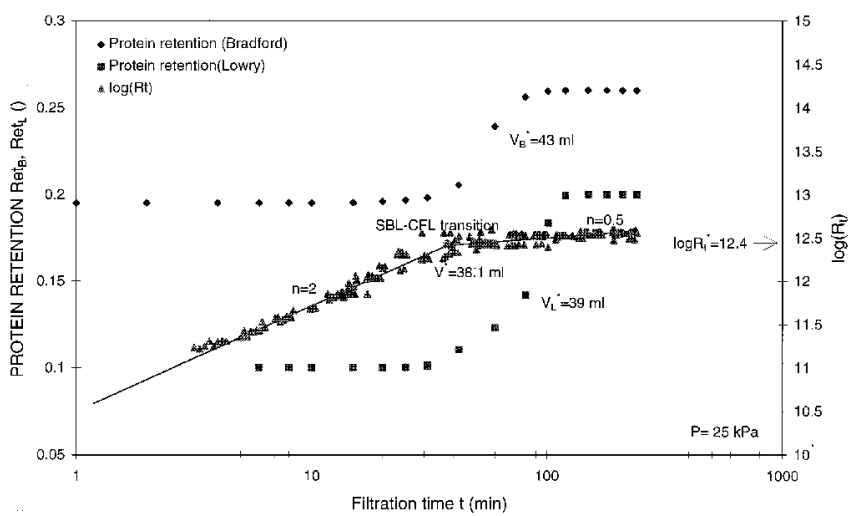

Figure 8. (a) Variation of protein retention $\left(\operatorname{Ret}_{B}, \operatorname{Ret}_{L}\right)$ and total membrane resistance $\left(R_{t}\right)$ with time for clarified beer microfiltration on a $0.2 \mu \mathrm{m}$ PC membrane. Experimental conditions: $P=25 \mathrm{kPa} ; 850 \mathrm{rpm} ; 0^{\circ} \mathrm{C}$.

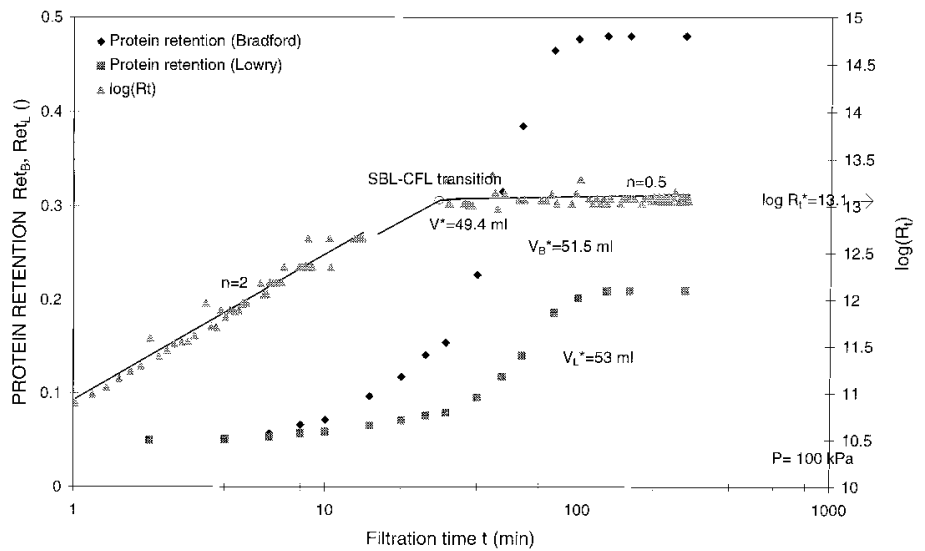

Figure 8. (b) Variation of protein retention $\left(\operatorname{Ret}_{B}, \operatorname{Ret}_{L}\right)$ and total membrane resistance $\left(R_{t}\right)$ with time for clarified beer microfiltration on a $0.2 \mu \mathrm{m}$ PC membrane. Experimental conditions: $P=100 \mathrm{kPa} ; 850 \mathrm{rpm} ; 0^{\circ} \mathrm{C}$.

of the protein retention step (i.e. $40<V_{B}{ }^{*}, V_{L} *<50 \mathrm{ml}$ ). Also the SBL-CFL transition takes place at a membrane resistance $R_{t}^{*}$ which is about one order of magnitude higher at $100 \mathrm{kPa}\left(R_{t}^{*} \approx 10^{13} \mathrm{~m}^{-1}\right)$ than at $10 \mathrm{kPa}\left(R_{t}^{*} \approx 10^{12} \mathrm{~m}^{-1}\right)$. The increase of $R_{t}^{*}$ with transmembrane pressure is in agreement with the fact that at the end of the SBL period, the loss of membrane permeability was substantially higher at $P=100 \mathrm{kPa}$ due to a larger thickness of the deposited layer onto the pore wall (see the values of $\left(L_{p}-L_{p 0}\right) / L_{p 0}{ }^{b}$ and $\delta^{b}$ in Table 3).

\section{Relationship between fouling mechanisms and protein} retention: results

For some filtration runs, the recording of permeate flux 
Table 4. Calculated values of $R_{\mathrm{t}}^{*}$ and $V^{*}$ at the transition from SBL to CFL for the various membrane fouling experiments on a $0.2 \mu \mathrm{m}$ PC membrane.

\begin{tabular}{lllll}
\hline$P=10 \mathrm{kPa}$ & $V^{*}(\mathrm{ml})$ & $14.1-14.4$ & $38.1-38.5$ & $33.2-33.5$ \\
$P=10 \mathrm{kPa}$ & $\log \left(R_{\mathrm{t}}^{*}\right)$ & $11.78-11.9$ & $12.04-12.15$ & $11.93-12.08$ \\
$P=100 \mathrm{kPa}$ & $V^{*}(\mathrm{ml})$ & $34.6-35.1$ & $19.3-19.6$ & $11.96-12.08$ \\
$P=100 \mathrm{kPa}$ & $\log \left(R_{\mathrm{t}}^{*}\right)$ & $12.96-12.99$ & $12.95-13.08$ & $37.3-38$ \\
\hline
\end{tabular}

Table 5. Calculated values of $R_{\mathrm{t}}^{*}, V^{*}, V_{B}^{*}$ and $V_{L}^{*}$ for the various membrane fouling runs with protein retention measured in parallel on a $0.2 \mu \mathrm{m} \mathrm{PC}$ and $\mathrm{Al}_{2} \mathrm{O}_{3}$ membrane.

\begin{tabular}{|c|c|c|c|c|c|c|c|}
\hline Membrane & $P(\mathrm{kPa})$ & $\log \left(R_{\mathrm{t}}^{*}\right)$ & $V^{*}(\mathrm{ml})$ & $V_{\mathrm{B}}^{*}(\mathrm{ml})$ & $V_{\mathrm{L}}^{*}(\mathrm{ml})$ & $\begin{array}{c}V^{*} / V_{\mathrm{B}}^{*}() \\
\text { (Bradford) }\end{array}$ & $\begin{array}{l}V^{*} / V_{\mathrm{L}}^{*}() \\
\text { (Lowry) }\end{array}$ \\
\hline PC membrane & 25 & 12.4 & 38.1 & 43 & 39 & 0.88 & 0.97 \\
\hline $\mathrm{Al}_{2} \mathrm{O}_{3}$ & 25 & $12.52-12.65$ & 47 & 55 & 51 & 0.85 & 0.92 \\
\hline membrane & 100 & $12.97-13.17$ & 82.3 & 89 & 89 & 0.92 & 0.92 \\
\hline
\end{tabular}

parallel to beer sampling in the permeate allowed us to evaluate both $R_{t}$ and $\operatorname{Ret}_{B}, \operatorname{Ret}_{L}$ as a function of time. A representative result of the variation of $R_{t}$ and $\operatorname{Ret}_{B}, \operatorname{Ret}_{L}$ with time (in logarithmic scale) in the course of the filtration is presented in Figures $8(\mathrm{a})$ and $8(\mathrm{~b})$ at $25 \mathrm{kPa}$ and $100 \mathrm{kPa}$ on a PC membrane. As for the membrane fouling runs (see Table 4), it is observed the SBL-CFL transition (characterized by the change of slope of the $\operatorname{linear} \log \left(\mathrm{R}_{t}\right)$ vs $\log (\mathrm{t})$ curve) at a membrane resistance $R_{t}{ }^{*}$ that is noticeably higher at $100 \mathrm{kPa}\left(R_{t}^{*}=1.3 \times 10^{13} \mathrm{~m}^{-1}\right.$ compared with $R_{t}^{*}=2.5 \times 10^{12} \mathrm{~m}^{-1}$ at $\left.25 \mathrm{kPa}\right)$.

Figures 8 (a) and 8 (b) clearly show that the step of protein retention coincides with the transition from SBL to CFL. Indeed the protein retention step occurs at filtrate volumes $V_{B}{ }^{*}$ and $V_{L}{ }^{*}$ which are close (and slightly higher) to the filtrate volume $V^{*}$ at the SBL-CFL transition.

In an attempt to quantify this observation, protein retention step has been defined by two parameters $V_{B}$ * and $V_{L} *$ corresponding to the filtrate volume at the inflection point of the fitted Ret versus $V$ curve for Bradford and Lowry methods, respectively (as shown in Figures 2(a) and 2(b)). Table 5 summarizes calculated filtrate volume values related to both the SBL-CFL transition and the protein retention step for the various filtration runs on a $\mathrm{PC}$ membrane as well as for two comparative ones on a $\mathrm{Al}_{2} \mathrm{O}_{3}$ membrane.

It can be seen in Table 5 that for both pressures and membrane types, the ratios $V^{*} / V_{B}{ }^{*}$ and $V^{*} / V_{L}{ }^{*}$ are remarkably close and range between $0.85-0.96$ and $0.92-$ 0.97 for Bradford and Lowry methods. This indicates that under the experimental conditions used, the step of protein retention is linked to the SBL-CFL transition (with a relation of the type: $V_{B, L}{ }^{*}-V^{*} \approx 0$ ) and occurs simultaneously with the SBL-CFL transition due to the sieving effect of the build-up of a fouling layer (or gel layer) at the solution-membrane interface.

The fouling and protein retention mechanism is probably the following one: in the first minutes of filtration $(t<5 \mathrm{~min})$, when the specific surface area and the permeability of the membrane are large enough, macrosolutes penetrate and are adsorbed within it. Then deposition of macrosolutes on the walls of the pore takes place (mainly a macrosolutemacrosolute interaction induced by flow through the pore), which conforms to SBL. At this stage the ratio between pore size and protein size is very high so that protein retention is low and constant. The SBL period results in decreasing the apparent pore size. Then macrosolutes are progressively rejected and start accumulating on the membrane surface; at this stage the filtration starts conforming to CFL and protein retention increases sharply. A fouling layer associating the macrosolutes forms over the membrane surface which is sensitive to operating conditions, i.e. tangential velocity and transmembrane pressure. Protein retention (governed by the sieving effect of the fouling layer) stabilizes at a level which is all the higher at large transmembrane pressure as the fouling layer is compressible.

These phenomena have been highlighted on a polycarbonate membrane. Its hydrophobic nature is supposed to enhance adsorption of beer proteins and to increase the fouling phenomena. It is shown that these phenomena are also valid for an aluminium oxide membrane whose nature and porous structure are different (hydrophilic and much more porous). Table 5 shows that the SBL-CFL transition occurs at a membrane resistance $R_{t}^{*}$ which is close to that found for the polycarbonate membrane. It happens at a filtrate volume $V^{*}$ which is noticeably greater for a given applied pressure. It is suggested that the SBL-CFL transition and the following protein retention step are postponed for the aluminium oxide membrane whose internal pore surface area is far higher $\left(S_{s p} \approx 1400\right.$ compared with $S_{s p} \approx 20$ for the polycarbonate membrane). In such conditions, and assuming a fouling parameter $C$ close to that for the polycarbonate membrane, the rate of growth of the layer thickness deposited onto the pore wall $(\delta)$ per unit filtrate volume over the SBL period is expected to be lower so that a larger filtrate volume is required to reach a given apparent pore size. In other words because of its large internal surface area, the aluminium oxide membrane exhibits a higher retention capacity.

\section{CONCLUSIONS}

This study has shown that internal and external membrane fouling has a major effect on permeate flux decline and selectivity to macrosolutes during the cold sterile microfiltration of beer on a hydrophobic organic membrane. 
Experimental results, fitted to the constant pressure blocking filtration laws, have been interpreted as a transition from an internal clogging of the pores (conforming to SBL) to an external fouling at the solution-membrane interface (conforming to CFL).

Both the internal and external fouling increase with transmembrane pressure. This could be quantified from the calculation of the fouling parameters $C$ and $\alpha C_{b}$ of SBL and CFL respectively, which have been found to increase gradually with transmembrane pressure. The detrimental effect of transmembrane pressure on internal fouling is thought to arise from denaturation effects under high shear stresses in the pores. For external fouling, the hydraulic resistance of the surface fouling layer increases with transmembrane pressure due to its high compressibility.

Protein-membrane interactions (adsorption/deposition processes) play a significant role in both the internal and external fouling of a hydrophobic organic membrane. The substantial protein rejection (up to $60 \%$ ) observed over the quasi-steady flux phase could be related to the build-up of a composite membrane (also called a 'secondary dynamic membrane') partially permeable to the high molecular weight $(>5,000)$ polypeptides in beer. The constant protein retention level over the CFL period generally increases with transmembrane pressure due to the hindered transport of proteins through a composite membrane of high hydraulic resistance.

Such fouling and protein retention mechanisms were also found to be valid for an aluminium oxide membrane although its nature and porous structure were different (hydrophilic and much more porous). The build-up of a compressible composite membrane of reduced porosity is probably responsible for the loss of essential quality components (such as proteins) in the filtrate generally observed in beer crossflow microfiltration. This study suggests that an appropriate way to improve the performances of the cold sterile microfiltration of beer consists of using a low protein binding membrane which would prevent the progressive internal pore blocking and the following formation of a colloidal film on the membrane surface. In addition, excessive internal and external fouling can be brought down by filtering at a moderate transmembrane pressure.

\section{APPENDIX}

\section{Constant Pressure Blocking Filtration Laws}

\section{Complete blocking filtration law}

It is considered that each solute, such as particles and colloids $\left(\mathrm{d}_{s} \sim \mathrm{d}\right)$, reaching the membrane blocks a pore (pore sealing) with no superposition of solutes. Con-sequently, the active area of the membrane $A$ is assumed to decrease proportionally to the filtrate volume $V$ according to:

$$
d A=-\sigma d V
$$

where $\sigma\left(\mathrm{m}^{-1}\right)$ is the blocked area per unit filtrate volume. Integrating equation (2) as $A=A_{0}-\sigma V$ and combining with Darcy's law yields,

$$
Q=Q_{0}-K_{b} V
$$

which is the linear relationship between $V$ and $Q$, where $Q_{0}$ is the initial flow rate and $K_{b}$ a constant given by:

$$
K_{b}=\frac{P \sigma}{\mu R_{t}}
$$

The fouling parameter $\sigma$ should be a function of solute concentration and size as well as physicochemical characteristics.

\section{Intermediate blocking filtration law}

It is considered that each solute $\left(d_{s} \sim d\right.$ as in the previous law) reaches the membrane at any location of the membrane and can settle on other solute previously arrived and already blocking some pores. The rate of decrease of active membrane area $A$ is proportional to $Q$ and to the active area itself:

$$
\frac{d A}{d V}=-\sigma \frac{A}{A_{0}}
$$

By integrating equation (4), we get:

$$
A=A_{0} \cdot e^{-\sigma V / A_{0}}
$$

Introducing Darcy's law in this last relation yields:

$$
Q=Q_{0} \cdot e^{-K_{i} V}
$$

where the constant $K_{i}\left(\mathrm{~m}^{-3}\right)$ is equal to

$$
\frac{\sigma P}{\mu R_{t} Q_{0}}=\frac{\sigma}{A_{0}} \text {. }
$$

Integrating eqn.(5) yields the $Q=f(t)$ relationship,

$$
\frac{1}{Q}=\frac{1}{Q_{0}}+K_{i} t
$$

\section{Standard blocking filtration law}

The standard law consists in a lateral adsorption or deposition of solute $\left(d_{s}<<d\right)$ resulting in a gradual pore volume decrease proportional to filtrate volume. The membrane is assumed to be composed of a bundle of regular cylindrical pores. If $r$ denotes the instantaneous pore radius and $\mathrm{N}$ is the number of pores, we can write:

$$
-N(2 \pi r \mathrm{~d} r) L=C \mathrm{~d} V
$$

where $L$ is the pore length and $C$ a dimensionless parameter representing the volume of solute deposited by unit filtrate volume. This parameter characterizes the potential of the solution for internal fouling via interfacial phenomena (electrokinetic and adsorption processes).

According to the Poiseuille's law, the flow rate through membrane pores is given by:

$$
Q=\frac{d V}{d t}=N\left(\frac{\pi}{8} \cdot \frac{r^{4} P}{\mu L}\right)
$$

Integrating equation (7) and combining with equation (8), it is possible to derive the following relation:

$$
Q=Q_{0}\left(1-\frac{K_{s} V}{2}\right)^{2}
$$

where the constant $K_{s}$ is equal to $2 C / L A_{0}$.

Integrating equation (9) yields the $V f(t)$ relationship:

$$
\frac{t}{V}=\frac{1}{Q_{0}}+\frac{K_{s} t}{2}
$$




\section{Cake filtration law}

The cake filtration model may be applied when solute size is larger than pore size $\left(d_{s}>d\right)$ or when the pores are sufficiently clogged to such an extent that the pores are smaller than the solute size. Solutes deposit over the membrane surface to form a cake (or fouling) layer. The basic assumption is that the cake resistance is proportional to the cumulative filtrate volume so that the total resistance to filtration is:

$$
R_{t}=R_{m}+M \alpha
$$

where $R_{m}$ is the membrane resistance $\left(\mathrm{m}^{-1}\right), M$ the cake loading (mass of cake per unit membrane area, $\mathrm{kg} \mathrm{m}^{-2}$ ) and $\alpha$ the specific resistance of the cake $\left(\mathrm{m} \mathrm{kg}^{-1}\right)$. As for conventional filtration, the flow rate is given by:

$$
Q=\frac{d V}{d t}=\frac{P S}{\mu\left(R_{m}+M \alpha\right)}
$$

In the absence of crossflow (i.e. conventional 'dead-end' filtration) the cake mass grows since,

$$
M=V C_{b} t
$$

and when equations (12) and (13) are combined, integrated and solved for $\mathrm{V}$, the $V=f(t)$ relationship is obtained:

$$
\frac{t}{V}=\frac{1}{Q_{0}}+\frac{K_{c} V}{2}
$$

where the constant $K_{c}$ is equal to $\alpha C_{b} \mu / S^{2} P$.

The parameter $\alpha$, like $\sigma$ and $C$, is a parameter characterizing the fouling potential of the solution for the case of external membrane fouling due to the accumulation of polarized solutes over the membrane surface.

\section{NOMENCLATURE}

$S_{s p}$

$t$

V

$V^{*}$

$V_{B}$ *

$V_{L}{ }^{*}$ specific surface area of the membrane (total surface area/ membrane surface area) (-)

filtration time (sec)

filtrate volume $\left(\mathrm{m}^{3}\right)$

filtrate volume corresponding to the change of slope of the straight lines of a plot of $\log \left(\mathrm{R}_{\mathrm{t}}\right)$ versus $\log (\mathrm{t})\left(\mathrm{m}^{3}\right)$

* filtrate volume at the inflection point of the fitted Ret versus $\mathrm{V}$ curves for the Bradford protein assay $\left(\mathrm{m}^{3}\right)$

filtrate volume at the inflection point of the fitted Ret versus $\mathrm{V}$ curves for the Lowry

protein assay $\left(\mathrm{m}^{3}\right)$

Greek symbols

$\alpha \quad$ specific cake resistance $\left(\mathrm{mkg}^{-1}\right)$

$\delta \quad$ mean thickness of deposited layer deposited onto the pore wall (m)

$\delta_{a d s} \quad$ mean thickness of adsorbed protein layer deposited onto the pore

wall $(\mathrm{m})$

$\Delta \mathrm{d} \quad$ mean membrane pore diameter decrease $(\mathrm{m})$

$\Delta \mathrm{d}_{a d s} \quad$ mean membrane pore diameter decrease due to protein adsorption $(\mathrm{m})$

$\varepsilon \quad$ cake voidage

$\mu \quad$ dynamic filtrate viscosity $\left(\mathrm{kg} \cdot \mathrm{m}^{-1} \cdot \mathrm{s}^{-1}\right)$

$\rho_{\mathrm{s}} \quad$ specific mass of solute $\left(\mathrm{kg} \cdot \mathrm{m}^{-3}\right)$

Abbreviations

B Bradford

CFL cake filtration law

CFMF crossflow microfiltration

L Lowry

PC polycarbonate

SBL standard blocking filtration law

\section{REFERENCES}

1. Ryder, D.S., Davis, C.R., Anderson, D., Glancy, F.M. and Power, J.N., 1988, Brewing experience with cross-flow filtration, MBAATechnical Quarterly, 25: 67-79.

2. Beer, C., 1989, Sterile filtration of beer, MBAA Technical Quarterly, 26: 89-93.

3. Schaub, H.P. and Dickmann, H., 1997, Criteria for cold sterile beer filtration with membrane filter cartridges, Brauwelt International, 15(2): 124-128.

4. Back, W., Leibhard, M. and Bohak, I., 1992, Flash pasteurizationmembrane filtration. Comparative biological safety, Brauwelt International, I: 42-49.

5. Reed, R., 1989, Advances in filtration, The Brewer, September, 9: 965970.

6. Reed, R.J.R., Evans, S.P., Taylor, D.G. and Anderson, H.J., 1989, Single stage downstream of beer using pulsed crossflow filtration, $22^{\text {nd }}$ European Brewery Convention Congress, Zürich, pp 413-424.

7. O'Reilly, S.M.G., Lummis, D.J., Scott, J. and Molzahn, S.W., 1987, The application of ceramic filtration for the recovery of beer using pulsed crossflow filtration, 21 $1^{\text {st }}$ European Brewery Convention Congress, Madrid, pp 639-646.

8. Lenoel, M., 1990, Beer recovery from yeast slurries and tank bottoms from pilot to industrial results, European Brewery Convention, Monograph XVI: Separations Processes, EBC Symposium, Leuven, Belgium, pp 128-139.

9. Lenoel, M., Blanpain, P., Weishaupt, R. and Shingleton, M., 1993, Modélisation de la microfiltration tangentielle de biere sur membranes-Compréhension du mécanisme de colmatage, Proceedings of the $24^{\text {th }}$ European Brewery Convention Congress, Oslo, Verlag Hans Carl (eds), Nürnberg (Germany), pp. 683-690.

10. Lenoel, M., Blanpain, P. and Taylor, J., 1994, Rational design of a cleaning procedure for microfiltration membranes, MBAA Technical Quarterly, 31: 134-137.

11. Blanpain, P., Lalande, M., 1997, Investigation of fouling mechanisms governing permeate flux in the crossflow microfiltration of beer, Filtration \& Separation, 34(10), December, pp 1065-1069.

12. Fillaudeau, L., Blanpain-Avet, P. and Lalande, M., 1998, Fouling mechanisms in beer crossflow microfiltration with tubular ceramic membrane, (Session II Membranes), in Fouling and Cleaning in Food Processing, Jesus College, 6-8 April 1998, Cambridge (UK).

13. Burrell, K.J. and Reed, R.J.R., 1994, Crossflow microfiltration of beer: Laboratory-scale studies on the effect of pore size, Filtration \& Separation, June, 31(4): 399-405. 
14. Gan, Q., Field, R.W., Bird, M.R., England, R., Howell, J.A., McKechnie, M.T. and O'Shaughnessy, C.L., 1997, Beer clarification by cross-flow microfiltration: fouling mechanisms and flux enhancement, Trans IChemE, Chem Eng Res Des, 75(A1): 3-8.

15. Blanpain, P., Hermia, J. and Lenoel, M., 1993, Mechanisms governing permeate flux and protein rejection in the microfiltration of beer with a Cyclopore membrane, J Membrane Sci, 84: 37-51.

16. Gan, Q., Howell, J., Field, R.W. and England, R., 1994, Fouling and backflush in beer clarification using ceramic membranes, Proceedings of IChemE Food Process Engineering Conference, 19-21 September, Bath (UK).

17. McKechnie, M.T., Burrell, K.J., Gill, C. and Kotzian, R., 1994, Ceramic membrane filtration of beer, Proceedings of IChemE Food Process Engineering Conference, 19-21 September, Bath (UK).

18. Hermia, J., 1982, Constant pressure blocking filtration lawsApplication to power-law non-Newtonian fluids, Trans Ind Chem Eng, 60: 183-187.

19. Analytica EBC, 1987, European Brewery Convention, Brauerei und Getränke-Rundschau, Zürich (Switzerland).

20. Hess, H.H., Lees, M.B. and Derr, J.E., 1978, A linear Lowry-Folin assay for both water soluble and sodium dodecyl sulfate-solubilized proteins, Anal Biochem, 85: 295-300.

21. Bradford, M.M., 1976, A rapid and sensitive method for the quantitation of microgram quantities of protein utilizing the principle of protein-dye binding, Anal Biochem, 72: 248

22. Lowry, O.H., Rosebrough, N.J., Farr, A.L. and Randall, R.J., 1951, Protein measurement with the folin phenol reagent, $J$ Biol Chem, 193: 265-275.

23. Lewis, M.J., Kaumland, S.C. and Muhleman. D.J., 1980, Dye-binding method for measurement of protein in wort and beer, American Society of Brewing Chemists Journal, 38(2), pp 37-41.

24. Hii, V. and Herwig, W.C., 1982, Determination of high molecular weight proteins in beer using Coomassie Blue, American Society of Brewing Chemists Journal, 40(2): 46-50.

25. Williams, K.M., Fox, P. and Marshall, T., 1995, A comparison of protein assays for the determination of the protein concentration of beer, J Inst Brew, Septembre-Octobre, 101: 365-369.

26. Lalande, M., Blanpain, P. and René, F., 1998, Applications: Bière, in Les S'eparations par Membrane dans les Procédes de l'Industrie Alimentaire, Daufin, G., René, F. and Aimar, P. (ed), Lavoisier Tec \& Doc (eds), Paris, pp 420-442.

27. Fane, A.G., Fell, C.J.D. and Waters, A.G., 1983, Ultrafiltration of protein solutions through partially permeable membranes-The effect of adsorption and solution environment, J Membrane Science, 16: $211-224$.
28. Chudacek, M.W. and Fane, A.G., 1984, The dynamics of polarization in unstirred and stirred ultrafiltration, J Membrane Science, 21: 145160 .

29. Hermia, J. and Brocheton, S., 1994, Comparison of modern beer filters, Filtration and Separation, November, 31(7): 721-725.

30. Loret, C., Chaufer, B., Sebille, B., Hanselin, M., Blain, Y. and Lehir, A., 1988, Characterization and hydrodynamic behavior of modified gelatin: II. Characterization by high performance size exclusion chromatography - Comparison with dextrans and proteins, Int J Biol Macromol, 10: 366-372.

31. Tiller, F.M., 1975, Compressible cake filtration, in The Scientific Basis of Filtration, Ives, K.J. (ed), Noordhoff, The Netherlands, p 315.

32. Norde, W., 1986, Adsorption of proteins from solution at the solidliquid interface, Adv Colloid Int Sci, 25: 267-340.

33. Franken, A.C.M., Sluys, J.T.M., Chen, V., Fane, A.G. and Fell, C.J.D., 1990 , Role of protein conformation on membrane characteristics, $5^{\text {th }}$ World Filtration Congress, Nice (France), Société Française de Filtration (ed), 1: 207-213.

34. Bowen, W.R. and Gan, Q., 1991, Properties of microfiltration membranes: Flux loss during constant pressure permeation of bovine serum albumin, Biotechnology and Bioengineering, 38: 688-696.

35. Visvanathan, C. and Ben Aïm, R., 1989, Studies on colloidal membrane fouling mechanisms in crossflow microfiltration, $J$ Membrane Sci, 45: $3-15$.

\section{ACKNOWLEDGEMENT}

The authors wish to thank the 'Terken' brewery in Roubaix, France for providing beer, and the Nord-Pas de Calais region for financial support.

\section{ADDRESS}

Correspondence concerning this paper should be addressed to Dr P. Blanpain-Avet, INRA-LGPTA, Centre de Recherches de Lille, 369 rue Jules Guesde, BP 39, 59651 Villeneuve d'Ascq Cedex, France.

The manuscript was received 22 October 1998 and accepted for publication after revision 5 March 1999.

This paper is an extended and updated version of a paper presented by the authors at Fouling and Cleaning in Food Processing, 6-8 April 1998, Cambridge, UK. 